\title{
Differences in age modulates neutrophils function
}

\author{
Claudia J. Lagranha ${ }^{1}$,Tatiana C. Alba-Loureiro ${ }^{2}$, Aline Isabel da Silva ${ }^{3}$, \\ Danuta Duarte Bezerra de Lima ${ }^{1}$, Anderson Apolonio Pedroza ${ }^{1}$, Diorginis Ferreira ${ }^{1}$, \\ Tania Pithon-Curi ${ }^{4}$ \\ ${ }^{1}$ Department of Physical Education and Sports Science, Federal University of Pernambuco, Vitoria de Santo Antão, Brazil \\ ${ }^{2}$ Department of Physiology and Biophysics, Institute of Biomedical Sciences, University of São Paulo, São Paulo, Brazil \\ ${ }^{3}$ Department of Nutrition, Federal University of Pernambuco, Recife, Brazil \\ ${ }^{4}$ Post-Graduate Program in Human Movement Science, Biological Sciences and Health Center, Cruzeiro do Sul University, \\ Sao Paulo, Brazil \\ Email: lagranha@hotmail.com
}

Received 9 January 2014; revised 10 February 2014; accepted 19 February 2014

Copyright (C 2014 Claudia J. Lagranha et al. This is an open access article distributed under the Creative Commons Attribution License, which permits unrestricted use, distribution, and reproduction in any medium, provided the original work is properly cited. In accordance of the Creative Commons Attribution License all Copyrights @ 2014 are reserved for SCIRP and the owner of the intellectual property Claudia J. Lagranha et al. All Copyright (C) 2014 are guarded by law and by SCIRP as a guardian.

\section{ABSTRACT}

The sexual maturation in all mammals is the period in which the quiescent gonads are activated by gonadotropins from anterior pituitary, increasing the secretion of sexual hormones. Sexual maturation is also related with the development of several other body features such as body mass and maturation of the circulatory, skeletal and hematopoietic systems. The aim of the present study was to evaluate the function of neutrophils submitted to in vivo lower and higher concentration of testosterone (sexually immature: 60 days and sexually mature: 90 days). Using different approaches we evaluated cell viability and function and gene expression in rat neutrophils from 60 and 90 days-old animals. Neutrophils from 90 days-old rats showed a decrease in phagocytic and fungicidal capacity, without change in cellular viability. Additionally, we verified that sexual maturation induced increase in production of reactive oxygen and nitrogen species (RONS) and also in TNF- $\alpha$, IL-6 and IL-10 cytokines. In conclusion, our data suggest that increase in testosterone levels induced significant alteration in neutrophil function, impairing phagocytic capacity.

\section{KEYWORDS}

Testosterone; Neutrophils Function;

NADPH-Oxidase Components; Sexual Maturation

\section{INTRODUCTION}

The sexual maturation in all mammals is the period in which the quiescent gonads are activated by gonadotropins from the anterior pituitary, increasing the secretion of sexual hormones [1]. It is an entailed condition to the hypothalamic-pituitary-gonadal axis and it has interaction with other hormones such as Growth Hormone, Insulin Growth Factor-1, Triiodothyronine, Thyroxine, Thyroid-Stimulating Hormone, Luteinising Hormone-Releasing Hormone [2,3]. It is also related with the development of several systems such as body mass and maturation of skeletal, circulatory and hematopoietic systems $[4,5]$.

The hormone testosterone is responsible for the development and maintenance of the characteristics of the masculine sex. Moreover, it increases protein build-up in muscles, bones and skin. In the hematopoietic system, testosterone augments the concentration of hemoglobin and the number of red cells [6]. Beyond these effects, testosterone is also responsible for the modulation of immune responses [7]. Previous study demonstrated that in Jurkat cells (human $\mathrm{T}$ cell lymphoblasts), this hormone inhibits their proliferation and maximizes the ratio of cells in phase SG to M of the cellular cycle [8]. Similar effect was observed in the Raji cell line (human B cell lymphoma) [8].

In addition to the above effects of testosterone, sex hormones seem to have a considerable influence on humoral and cellular immunity, which may lead to sex differences in immune responses. Regarding cytokine production and release, there are still controversial results. Another group studying the effect of sex hormones in cytokine production have shown higher levels of interferon (IFN)- $\gamma$ and IL-2 and lower levels of IL-10 and IL-4 secretion by male lymphocytes when compared to 
lymphocytes from female donors [9]. In contrast, another group [10] studying differences in type 1 and 2 cytokines from male and female human lymphocytes, found a decrease in the numbers of IL-2-positive lymphocytes from males compared to females, whereas no differences were found in the percentage of IL-4-, IL-10- and IFN- $\gamma$-producing lymphocytes. Additionally, these authors also demonstrated an increase in the percentage of lipopolysaccharide-stimulated, IL-12-, IL- $1 \beta$ - and TNF- $\alpha$-positive monocytes collected from male donors when compared with their female counterparts.

Posma's group investigating whether testosterone may be responsible for the differences between sexes related to the production of IL-2, IFN- $\gamma$, IL-12, IL- $1 \beta$ and TNF$\alpha$, observed a significant expansion of IL-12- and IL- $1 \beta$ producing monocytes after incubation with physiological concentrations of testosterone [11]. Interestingly, the percentages of IL-2- and IFN- $\gamma$-positive lymphocytes and TNF- $\alpha$-producing monocytes were not altered by testosterone [11]. In contrast, Janele et al. (2006) showed that joint treatment with cortisol and testosterone inhibited production of IL-2, IL-4, IL-10 and reduced the secretion of TNF- $\alpha$ and IFN- $\gamma$ by human leukocytes, although, no changes were found with treatment with testosterone only [12]. Some of the differences cited above may be due to the cell type involved, hormone concentration or be specie-specific, nevertheless, they strongly indicate that sex hormones are able to induce immunomodulation.

Testosterone concentration rises 8-fold in the plasma of Wistar rats aged 90 days when compared to counterparts 60 days-old [13]. With this information in mind, the present study was undertaken to investigate the physiologic influence of testosterone on the function of rat neutrophils. The following parameters were examined: cell viability, DNA fragmentation, phagocytic and fungicidal capacity, reactive oxygen and nitrogen species (RONS) production, cytokine production and NADPHoxidase components (p22 ${ }^{\text {phox }}, \mathrm{p} 47^{\text {phox }}$, gp91 ${ }^{\text {phox }}$ and Rac2) expression.

\section{MATERIAL AND METHODS}

\subsection{Animals}

Male Wistar rats used in this study were obtained from the Department of Physiology and Biophysics, Institute of Biomedical Sciences, University of São Paulo. The rats were maintained at standard conditions, being allowed free access to food and water. The Animal Ethical Committee of the Institute of Biomedical Sciences approved all experimental procedures.

\subsection{Neutrophil Isolation}

Rats were euthanized at 60 and 90 days of age. Neutrophils were obtained by intraperitoneal (i.p.) lavage with
$30 \mathrm{~mL}$ of phosphate-buffered saline (PBS), 4 hours after the injection (i.p.) of $10 \mathrm{~mL} \mathrm{1 \% (w/v)} \mathrm{glycogen} \mathrm{solution}$ (Oyster glycogen type II, Sigma Chemical Co., St. Louis, MO, USA) in PBS. The cell suspension was centrifuged at $4^{\circ} \mathrm{C}(1000 \mathrm{~g}$ for $10 \mathrm{~min})$ [14-18].

\subsection{Cell Viability}

Neutrophils $\left(1 \times 10^{6}\right.$ cells $)$ were centrifuged at $500 \mathrm{~g}$ for $15 \mathrm{~min}$ at $4^{\circ} \mathrm{C}$ and the pellet obtained was resuspended in $500 \mu \mathrm{L}$ PBS and incubated with propidium iodide (PI) (50 $\mu \mathrm{g} / \mathrm{mL}$ ) for 5 minutes. After incubation at RT the cells were evaluated in a FACScalibur ${ }^{\mathrm{TM}}$ flow cytometer (Becton Dickinson, San Juan, CA, USA) with assistance of the Cell Quest ${ }^{\mathrm{TM}}$ software (Becton Dickinson). The equipment was set to identify live and dead cells using the FL2 channel $[14,17,19,20]$.

\subsection{DNA Fragmentation Assay}

DNA fragmentation was analyzed by flow cytometry after DNA staining with PI according to the method described by Nicoletti et al. (1991) [21]. Neutrophils $(1 \times$ $10^{6}$ cells) were suspended in a solution containing $50 \mu \mathrm{g} /$ $\mathrm{mL}$ PI, $0.1 \%$ sodium citrate, and $0.1 \%$ Triton X-100. The cells were then incubated for $30 \mathrm{~min}$ at RT. Fluorescence was measured and analyzed by flow cytometry $[14,19$, 20].

\subsection{Phagocytosis}

Neutrophils $\left(1 \times 10^{6}\right.$ cells) were incubated for $40 \mathrm{~min}$ at $37^{\circ} \mathrm{C}$ in $1 \mathrm{~mL}$ RPMI 1640 (Gibco $^{\mathrm{TM}}$, Invitrogen Co., Carlsbad, CA, USA) with opsonized particles of zymosan (Sigma Chemical Co.). The particles $\left(1 \times 10^{7}\right)$ were opsonized by incubation in the presence of control rat serum for $30 \mathrm{~min}$ at $37^{\circ} \mathrm{C}$. Cells were stained with crystal violet and counted in a Neubauer chamber. The percentage of phagocytosis was expressed by the number of cells that had ingested three or more particles of opsonized zymosan per total number of cells counted [22].

\subsection{Fungicidal Capacity}

In the fungicidal assay, Candida albicans were firstly cultured onto Sabouraud agar tubes and incubated at RT during 12 hours. Afterwards, spores $\left(1 \times 10^{7}\right)$ were opsonized by incubation in the presence of serum from control rats for $30 \mathrm{~min}$ at $37^{\circ} \mathrm{C}$. Neutrophils $\left(1 \times 10^{6}\right)$ in 1 $\mathrm{mL}$ of RPMI 1640 supplemented with $10 \%$ fetal bovine serum were incubated at $37^{\circ} \mathrm{C}$ for 60 min with the opsonized spores. After incubation, $200 \mu \mathrm{L}$ of these samples were processed in a cell spin cytocentrifuge and the slides containing the attached cells were stained with May-Grunwald-Giemsa dye. Different scores were given to the number of neutrophils that had not killed C. albi- 
cans cells $(\times 0)$; 1 or 2 cells $(\times 1)$; 3 or 4 cells $(\times 2)$; or $>4$ cells $(\times 3)$. The index of fungicidal capacity was calculated by the sum of the scores obtained per rat [23,24].

\subsection{Evaluation of Superoxide Production after Phagocytosis}

Luminol (Santa Cruz Biotechnology) (1 mM) was added to neutrophils $\left(2.5 \times 10^{6}\right.$ cells/mL) in PBS buffer supplemented with $\mathrm{CaCl}_{2}(1 \mathrm{mM}), \mathrm{MgCl}_{2}(1.5 \mathrm{mM})$, and glucose $(10 \mathrm{mM})$, at $37^{\circ} \mathrm{C}$, in a final volume of $0.3 \mathrm{ml}$. The cells were treated with opsonized zymosan $\left(1 \times 10^{7}\right.$ particles/mL) [25]. The superoxide production was monitored for $20 \mathrm{~min}$, at $37^{\circ} \mathrm{C}$, in a microplate luminometer (EG \& G Berthold LB96V, Pforzheim, Germany).

\subsection{Hydrogen Peroxide Production}

Hydrogen peroxide $\left(\mathrm{H}_{2} \mathrm{O}_{2}\right)$ production was measured as previous described [26]. Briefly, the cells were incubated in the presence of $5 \mathrm{mM}$ glucose and a solution of phenol red $(0.5 \%)$ and horseradish peroxidase $(5 \mathrm{mg} / \mathrm{mL})$ at $37^{\circ} \mathrm{C}$ for $1 \mathrm{~h}$. The amount of product formed was measured by absorbance at $620 \mathrm{~nm}$ [22].

\subsection{Determination of Nitric Oxide}

The content of nitrite was measured in the supernatant of cultured cells based on the method described previously [27]. Briefly, cells $\left(5 \times 10^{5}\right)$ were cultured in 96 well plates for $24 \mathrm{~h}$. At the end of this period, $50 \mu \mathrm{L}$ of the supernatant was removed and incubated with an equal volume of Griess reagent at RT for $10 \mathrm{~min}$. The absorbance was determined at $550 \mathrm{~nm}$. Nitrite concentration was determined by using sodium nitrite as standard [15, 28].

\subsection{Cytokine Measurement}

Measurement of the cytokines was performed in the peritoneal cavity fluid by ELISA using Duo-set kits for IL-6 (R \& D Systems Inc., Minneapolis, MN, USA) and TNF- $\alpha$ and IL-10 (BD Pharmingen, San Jose, CA, USA), as described previously [29].

\subsection{RNA Extraction}

Total RNA was obtained from $1 \times 10^{7}$ neutrophils lysed by the guanidine isothiocyanate extraction method [30], using TRIzol reagent, according to the manufacturer's instructions (Invitrogen, Carlsbad, CA, USA). Briefly, homogenized samples were incubated $5 \mathrm{~min}$ at RT in order to allow the complete dissociation of nucleoprotein complexes. Chloroform $(0.2 \mathrm{~mL})$ was added and the tubes centrifuged at $12.000 \mathrm{~g}$ for $15 \mathrm{~min}$ at $2^{\circ} \mathrm{C}$ to $8^{\circ} \mathrm{C}$. The aqueous phase was transferred and the RNA precipitate was obtained by centrifugation with $0.5 \mathrm{~mL}$ of cold isopropyl alcohol [31]. The RNA pellet was washed with $75 \%$ ethanol and centrifuged at $7.500 \mathrm{~g}$ for $5 \mathrm{~min}$ at 2 to $8^{\circ} \mathrm{C}$. At the end, the RNA pellet was air-dried and stored at $-70^{\circ} \mathrm{C}$. RNA was quantified by measuring absorbance at $260 \mathrm{~nm}$ and it is purity assessed by the $260 / 280 \mathrm{~nm}$ ratio $[15,17,32]$.

\subsection{Reverse Transcription}

Total RNA $(1.5 \mu \mathrm{g})$ was treated with $1 \mathrm{U}$ of DNase I (Invitrogen), for $15 \mathrm{~min}$ at $25^{\circ} \mathrm{C}$, followed by enzyme inactivation with $25 \mathrm{mM}$ EDTA for $10 \mathrm{~min}$ at $65^{\circ} \mathrm{C}$. Afterwards, cDNA was synthesized in a solution containing 10 mM dNTP mix (dATP, dGTP, dCTP and dTTP, 10 $\mathrm{mM}$ each), $0.1 \mathrm{M}$ DTT and $200 \mathrm{U}^{\text {Superscript }}{ }^{\mathrm{TM}}$ II RNase $\mathrm{H}^{-}$Reverse Transcriptase (Invitrogen), incubated at $42^{\circ} \mathrm{C}$ for $50 \mathrm{~min}$. The reaction was inactivated by heating at $70^{\circ} \mathrm{C}$ for $15 \mathrm{~min}$ [15].

\subsection{Real Time Polymerase Chain Reaction}

Transcripts of NADPH-oxidase components were evaluated by real-time PCR [33] in a Rotor Gene ${ }^{\mathrm{TM}} 3000$ equipment (Corbett Research, Mortlake, Australia), using Platinum ${ }^{\circledR}$ SYBR ${ }^{\circledR}$ Green qPCR SuperMix UDG (Invitrogen). Gene expression was performed by $2^{-\Delta \Delta \mathrm{CT}}$ [34,35], using $\beta 2$-microglobulin $(\beta 2 \mathrm{M})$ gene as internal control [36]. The primers information's are shown in Table 1.

\section{STATISTICAL ANAL YSIS}

All results are expressed as means \pm SEM. Student $t$-test or ANOVA followed by the Tukey-Kramer test were used to assess significant differences between groups. Data were considered as statistically significant for $p \leq$ 0.05 .

\section{RESULTS}

Neutrophil counts were performed four hours after the injection of $10 \mathrm{~mL} 1 \%(\mathrm{w} / \mathrm{v})$ glycogen solution. Similar number of cells migrated to the peritoneal cavity of both groups, 60D ((rats 60 days-old): $14.9 \pm 1.1 \times 10^{7} \mathrm{SEM} ; n$ $=7)$ and 90D ((rats 90 days-old): $\left.15.8 \pm 1.1 \times 10^{7} ; n=9\right)$.

The percentage of viable neutrophils was not found different between the studied groups (60D: $96.5 \pm 1.1$ and 90D: $93.4 \pm 3.0$, Figure 1). Furthermore, the percentage of neutrophils with fragmented DNA in 90D $(6.0 \%$ $\pm 3.9 \%$ ) was not significantly different when compared with 60D group $(4.0 \% \pm 2.9 \%)$ (Figure 1$)$.

Phagocytosis and fungicidal capacity of neutrophils from 90D rats were decreased by 35\% and 34\%, respectively, as compared with 60D rats (Figures 2(a) and (b)). After analyzing the competence for superoxide production after stimulus with opsonized zymosan, we verified 
Table 1. Primer sequences, annealing temperatures and fragment lengths of the genes studied.

\begin{tabular}{|c|c|c|c|c|}
\hline \multirow{2}{*}{ Gene } & \multicolumn{4}{|c|}{ Primer sequences, annealing temperatures and lengths of the genes studied } \\
\hline & Primer Sense & Primer Anti-sense & $\begin{array}{c}\text { Annealing } \\
\text { temperature }\left({ }^{\circ} \mathrm{C}\right)\end{array}$ & $\begin{array}{c}\text { PCR fragment } \\
\text { lengths (bp) }\end{array}$ \\
\hline gp91 phox & GTGTGTGAATGCCAGAGTCGG & TTCCTGTGATGCCAGCCAAC & 54 & 164 \\
\hline $\mathrm{p} 47^{\text {phox }}$ & CACCTTCATTCGCCACATCGC & ACGCTGCCCATCATACCACCTG & 58 & 247 \\
\hline $\mathrm{p} 22^{\text {phox }}$ & CAGAAGTACCTGACCGCTGTGG & GGTAGATCACACTGGCAATGGC & 58 & 157 \\
\hline Rac2 & TCAAGTGTGTGGTGGTGGGTG & TGTCTGTGGGTAGGAGAGTGGC & 58 & 215 \\
\hline$\beta 2 \mathrm{M}$ & СTCAGTTCСАСССАССТСАG & GCAAGCATATACATCGGTCTCG & 56 & 82 \\
\hline
\end{tabular}

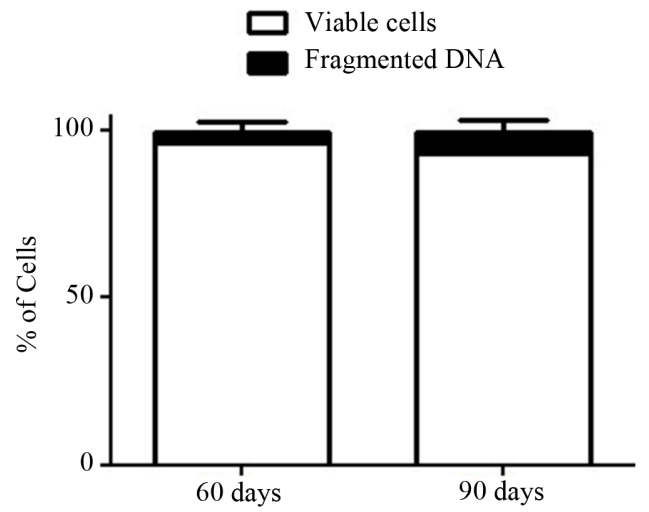

Figure 1. Percentages of neutrophils with intact plasma membrane and fragmented DNA. The values are from neutrophils obtained from six rats of each group and expressed as means \pm S.E.M.

that neutrophils from 90D group showed an increase (15.5\%) in production of superoxide anion (Figure 2(c)).

Evaluating the effect of sexual maturation in the production of RONS we observed that neutrophils from rats aged 90 days greatly enhanced the production of both $\mathrm{H}_{2} \mathrm{O}_{2}(130 \%)$ and nitrate (40\%) as compared with neutrophils originated from 60D rats (Figures 3(a) and (b)).

Regarding the capacity of neutrophils to produce cytokines (i.e. TNF- $\alpha$, IL-10 and IL-6) under higher physiological concentrations of testosterone (group 90D), we detected a significant increase in all cytokines evaluated (TNF- $\alpha=32.8 \%$; IL-10 = 46\% and IL-6 = 72\%; Figures 4(a)-(c)).

The effect of testosterone on NADPH-oxidase components (p22 $2^{\text {phox }}, \mathrm{p} 47^{\text {phox }}$, gp91 ${ }^{\text {phox }}$ and Rac2) was analyzed by Real Time PCR. Neutrophils obtained from 60D and 90D rats did not present statistically significant differences concerning the expression of the four genes studied (Figures 5(a)-(d)).

\section{DISCUSSION}

The major function of neutrophils is to kill microbial agents after phagocytosis, usually by an increase in the production of reactive oxygen and nitrogen species (RONS). In the present study, we demonstrated that the phagocytic competence of neutrophils from 90D rats was diminished. Our results corroborate with a previous study from Olinescu et al. (1994) who shown the effect of sexual hormones, testosterone and estrone, on the phagocytosis of rats neutrophils [37]. In their research, the authors presented evidence to support that testosterone in low concentrations (less than $10^{-5} \mathrm{M}$, in vitro) augmented phagocytosis in neutrophils. However, in higher concentrations, the sexual hormones (testosterone and estrona) inhibited the phagocytic capacity of these cells. Moreover, al-Afaleq \& Homeida (1998) showed that testosterone at $0.1 \mathrm{mg} / \mathrm{kg}^{-1}$ can induce significant reduction in phagocytic activities from chicken macrophages, suggesting that testosterone may possess immunosuppressant effects [38]. Recently, was demonstrated that treatment with $10 \mathrm{nM}$ of testosterone can increase the phagocytic activities of neutrophils, however, at concentrations of $0.1 \mu \mathrm{M}$ and $10 \mu \mathrm{M}$, the hormone does not induce any change on the phagocytic capacities of these cells [39]. Besides detecting a decline in phagocytic capacity, our study also demonstrated that neutrophils from 90D rats had impaired fungicidal activity. Our results confirm the findings of Marin's paper [39] where human neutrophils treated in vitro with $10 \mathrm{mM}$ of testosterone also had weak fungicidal capacity.

Regarding the production of reactive oxygen species in neutrophils from 90D rats we measured the amount of superoxide after phagocytosis of opsonized zymosan and $\mathrm{H}_{2} \mathrm{O}_{2}$ production. As showed in Figures 2 and 3, neutrophils from 90D rats exhibited elevated levels of superoxide and peroxide, which suggest that the impaired fungicidal capacity detected was derived from a failure in the phagocytosis stage. Our data are in contrast to Marin et al. (2010) and Bekesi et al. (2001) who observed that testosterone at $10 \mathrm{nM}$ and $0.1 \mu \mathrm{M}$ concentrations, were able to inhibit superoxide production [40]. This discrepancy may be due to methodological differences. In our study, superoxide production was evaluated after phagocytosis of opsonized zymosan and peroxide production 


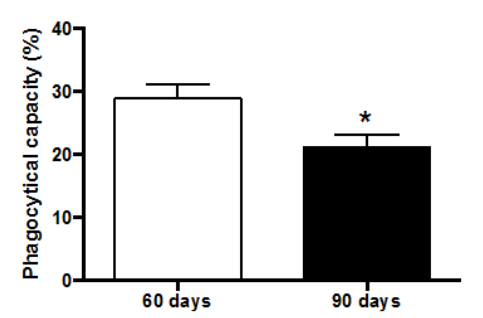

(a)

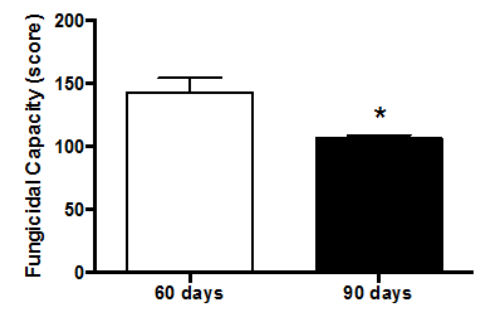

(b)

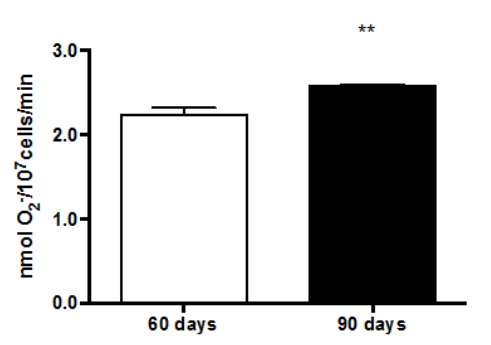

(c)

Figure 2. Phagocytic (a) and fungicidal (b) capacity, and (c) superoxide production from neutrophils at 60 and 90 days-old rats. For measurements of phagocytic and fungicidal capacity, neutrophils from five rats per group were evaluated. For superoxide production, neutrophils from six rats per group were evaluated. The values are expressed as means \pm S.E.M.

(a)

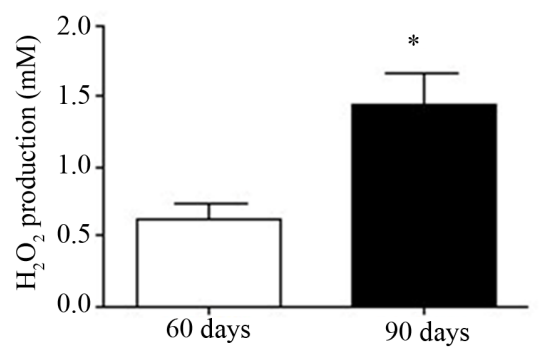

(b)

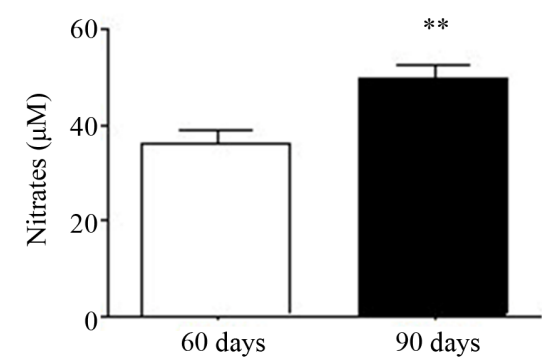

Figure 3. (a) $\mathrm{H}_{2} \mathrm{O}_{2}$-production; and (b) Nitric oxide production by neutrophils. The values are from six rats from each group and expressed as means \pm S.E.M.

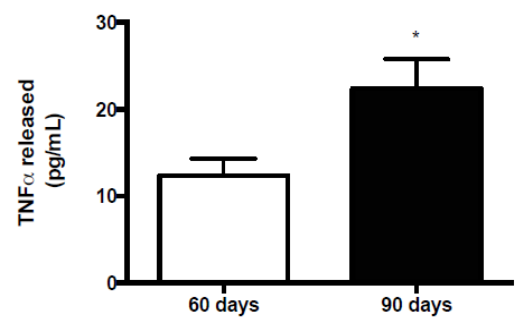

(a)

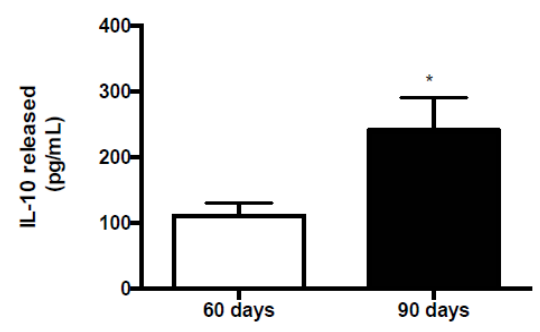

(b)

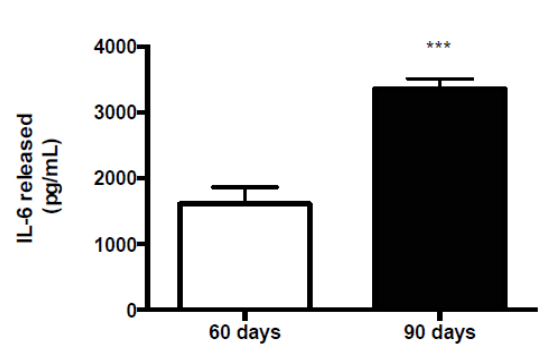

(c)

Figure 4. Cytokine production from neutrophils collected from 60 and 90 days-old rats. (a) TNF- $\alpha$; (b) IL-10; and (c) IL-6 levels were established for five rats in each group. The values are expressed as means \pm S.E.M.

by neutrophils without additional treatment with testosterone. On the other hand, Marin et al. (2010) used human neutrophils with additional in vitro treatment with testosterone for $24 \mathrm{~h}$. Bekesi et al. (2001), used mixed human neutrophils (male and females), with a high discrepancy of age (22 - 72 years), without testing the effect of physiological low levels of sex hormones [40]. We also believe that our findings in 90D rats could be compared to the control group found in each of the mentioned papers, although, we are unable to compare our results from rats aged 60D since the neutrophils from control groups in both articles [39,40], were derived from humans at mature age, where testosterone levels are found already at high concentrations. Despite the differ- ences in superoxide production, our data concerning nitric oxide production are in agreement to Marin's paper, where they showed additional effect of testosterone in nitric oxide production by neutrophils from young men.

Neutrophils from 90D rats produce significantly more TNF- $\alpha$, IL-6 and IL-10 than neutrophils from 60D rats. Data available in the scientific literature, related to the effect of testosterone in cytokine production from immune cells are very limited and controversial. GironGonzalez et al. (2000) studying the effect of sex hormones in cytokine production from male lymphocytes, observed low levels of IL-10 when compared to female counterparts [9]. In contrast, Bouman et al. (2004) found no differences in the percentages of IL-10-positive lym- 
(a)
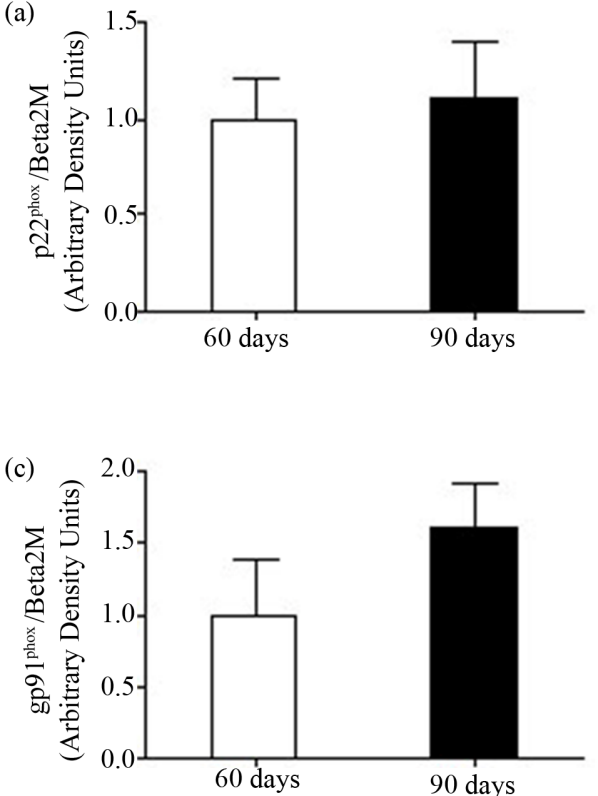

(b)

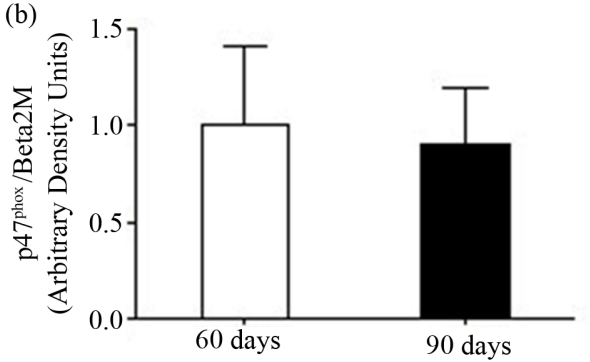

(d)

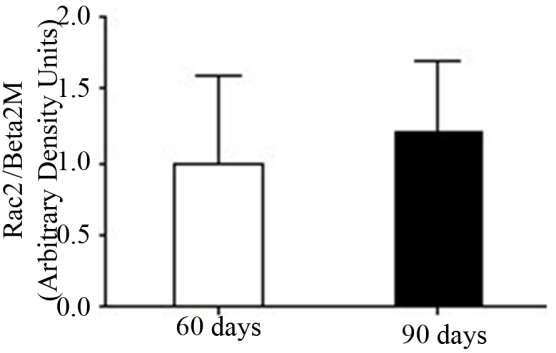

Figure 5. Expression of NADPH-oxidase components: (a) p22 ${ }^{\text {phox }}$; (b) p47 $7^{\text {phox }}$; (c) gp91 ${ }^{\text {phox }}$; and (d) Rac2 expression. The values are presented from four rats of each group and expressed as means \pm S.E.M.

phocytes between sexes. Measurements of monocytes stimulated with LPS [10] revealed an increase in the percentage of TNF- $\alpha$ positive cells in males when compared with females. In a recent study, Posma et al. (2004) investigating whether testosterone may be responsible for the differences in the production of cytokines, did not observe influence of this hormone on the production of TNF- $\alpha$ by monocytes [11]. Similar observation was made by Janele et al. (2006), showing no differences in IL-10 and TNF- $\alpha$ production by human leukocytes treated with testosterone [12]. Above all, we have not been able to track studies analyzing specifically the effect of physiological concentrations of the testosterone on the production of cytokines by neutrophils.

In the attempt to understand why neutrophils from $90 \mathrm{D}$ rats present a decrease in fungicidal capacity, we examined the expression of NADPH-oxidase components (gp91 ${ }^{\text {phox }}, \mathrm{p} 47^{\text {phox }}, \mathrm{p} 22^{\text {phox }}$ and Rac2) by Real-Time PCR. We did not detect any significant difference after sexual maturation of the animals. Our results are also in accordance with Sumi et al. (2003), when working with human monocytic cells, demonstrated a lack of inhibition of NADPH oxidase activity by testosterone, suggesting again that the impairment seen in fungicidal capacity may be due to the inability of these cells to phagocyte properly [41].

In conclusion, results presented herein establish an immunomodulation effect for the hormone testosterone in neutrophils. Furthermore, it also suggests that the immunosuppressant induced by testosterone is, in part, due to a dysfunction in the phagocytic capacity of neutrophils, which may lead to an impairment of the destruction process of fungi (i.e. fungicidal capacity). Further studies may be needed to better understand the effects of physiological concentrations of testosterone in the phagocytosis by neutrophils, in particular, focusing on the molecular mechanisms controlling phagocytosis.

\section{ACKNOWLEDGEMENTS}

The authors are grateful to J. R. Mendonça and E.P.P. Santos, for technical assistance, and FAPESP, CNPq, CAPES and Pronex, for financial support.

\section{REFERENCES}

[1] Bogin, E., Marom, M. and Levi, Y. (1994) Changes in serum, liver and kidneys of cisplatin-treated rats; effects of antioxidants. European Journal of Clinical Chemistry and Clinical Biochemistry, 32, 843-851.

[2] Amiel, S.A., et al. (1991) Insulin resistance of puberty: A defect restricted to peripheral glucose metabolism. The Journal of Clinical Endocrinology and Metabolism, 72, 277-282. http://dx.doi.org/10.1210/jcem-72-2-277

[3] Kiess, W., et al. (1995) Salivary cortisol levels throughout childhood and adolescence: Relation with age, pubertal stage, and weight. Pediatric Research, 37, 502-506. http://dx.doi.org/10.1203/00006450-199504000-00020

[4] Liker, H.R., et al. (1988) Blood pressure and body size in precocious puberty. Acta paediatrica Scandinavica, 77, 294-298. http://dx.doi.org/10.1203/00006450-199504000-00020

[5] Weaver, C.M., et al. (1996) Calcium retention estimated from indicators of skeletal status in adolescent girls and 
young women. The American Journal of Clinical Nutrition, 64, 67-70.

[6] Grumbach, M.M. and Styne, D.M. (1998) Puberty: Ontogeny, Neuroendocrinology, physiology and disorders. In: Willians Textbook of Endocrinol, 9th Edition, 15091625.

[7] Chao, T.C., Van Alten, P.J. and Walter, R.J. (1994) Steroid sex hormones and macrophage function: Modulation of reactive oxygen intermediates and nitrite release. American Journal of Reproductive Immunology, 32, 43-52. http://dx.doi.org/10.1111/j.1600-0897.1994.tb00877.x

[8] McMurray, R.W., et al. (2001) Differential effects of sex steroids on T and B cells: Modulation of cell cycle phase distribution, apoptosis and bcl-2 protein levels. Pathobiology, 69, 44-58. http://dx.doi.org/10.1159/000048757

[9] Giron-Gonzalez, J.A., et al. (2000) Consistent production of a higher TH1:TH2 cytokine ratio by stimulated T cells in men compared with women. European Journal of Endocrinology, 143, 31-36. http://dx.doi.org/10.1530/eje.0.1430031

[10] Bouman, A., et al. (2004) Gender difference in the nonspecific and specific immune response in humans. American Journal of Reproductive Immunology, 52, 19-26. http://dx.doi.org/10.1111/j.1600-0897.2004.00177.x

[11] Posma, E., et al. (2004) The effect of testosterone on cytokine production in the specific and non-specific immune response. American Journal of Reproductive Immunology, 52, 237-243. http://dx.doi.org/10.1111/j.1600-0897.2004.00216.x

[12] Janele, D., et al. (2006) Effects of testosterone, 17betaestradiol, and downstream estrogens on cytokine secretion from human leukocytes in the presence and absence of cortisol. Annals of the New York Academy of Sciences, 1069, 168-182. http://dx.doi.org/10.1196/annals.1351.015

[13] Zanato, V.F., et al. (1994) Sexual development of male Wistar rats. Brazilian Journal of Medical and Biological Research, 27, 1273-1280.

[14] Pithon-Curi, T.C., et al. (2003) Glutamine delays spontaneous apoptosis in neutrophils. American Journal of Physiology-Cell Physiology, 284, C1355-C1361. http://dx.doi.org/10.1152/ajpcell.00224.2002

[15] Lagranha, C.J., et al. (2005) The effect of glutamine supplementation on the function of neutrophils from exercised rats. Cell Biochemistry and Function, 23, 101-107. http://dx.doi.org/10.1002/cbf.1192

[16] Lagranha, C.J., et al. (2007) Glutamine supplementation prevents exercise-induced neutrophil apoptosis and reduces p38 MAPK and JNK phosphorylation and p53 and caspase 3 expression. Cell Biochemistry and Function, 25, 563-569. http://dx.doi.org/10.1002/cbf.1421

[17] Lagranha, C.J., et al. (2004) Beneficial effect of glutamine on exercise-induced apoptosis of rat neutrophils. Medicine \& Science in Sports \& Exercise, 36, 210-217. http://dx.doi.org/10.1249/01.MSS.0000113490.98089.B1

[18] Lagranha, C.J., et al. (2008) Neutrophil fatty acid composition: Effect of a single session of exercise and glutamine supplementation. Amino Acids, 35, 243-245. http://dx.doi.org/10.1007/s00726-007-0561-9
[19] Levada-Pires, A.C., et al. (2008) Neutrophil death induced by a triathlon competition in elite athletes. Medicine \& Science in Sports \& Exercise, 40, 1447-1454. http://dx.doi.org/10.1249/MSS.0b013e31816dc89e

[20] Levada-Pires, A.C., et al. (2010) The effect of an adventure race on lymphocyte and neutrophil death. European Journal of Applied Physiology, 109, 447-453. http://dx.doi.org/10.1007/s00421-010-1363-4

[21] Nicoletti, I., et al. (1991) A rapid and simple method for measuring thymocyte apoptosis by propidium iodide staining and flow cytometry. Journal of Immunological Methods, 139, 271-279. http://dx.doi.org/10.1016/0022-1759(91)90198-O

[22] Alba-Loureiro, T.C., et al. (2006) Diabetes causes marked changes in function and metabolism of rat neutrophils. Journal of Endocrinology, 188, 295-303. http://dx.doi.org/10.1677/joe.1.06438

[23] Sasada, M. and Johnston Jr., R.B. (1980) Macrophage microbicidal activity. Correlation between phagocytosisassociated oxidative metabolism and the killing of Candida by macrophages. The Journal of Experimental Medicine, 152, 85-98. http://dx.doi.org/10.1084/jem.152.1.85

[24] Sasada, M. et al. (1987) Candidacidal activity of monocyte-derived human macrophages: Relationship between Candida killing and oxygen radical generation by human macrophages. Journal Leukocyte Biology, 41, 289-294.

[25] Stevens, P. and Hong, D. (1985) The role of myeloperoxidase and superoxide anion in the luminol- and lucigenin-dependent chemiluminescence of human neutrophils. Microchemical Journal, 30, 11.

[26] Pick, E. and Mizel, D. (1981) Rapid microassays for the measurement of superoxide and hydrogen peroxide production by macrophages in culture using an automatic enzyme immunoassay reader. Journal of Immunological Methods, 46, 211-226.

http://dx.doi.org/10.1016/0022-1759(81)90138-1

[27] Ding, Y., Ma, K. and Tsui, Z.C. (1998) Induction of nitric oxide production by ganglioside GM3 in murine peritoneal macrophages activated for tumor cytotoxicity. In Vivo, 12, 357-361.

[28] de Lima, T.M., et al. (2006) Fatty acid control of nitric oxide production by macrophages. FEBS Letters, 580, 3287-3295.

http://dx.doi.org/10.1016/j.febslet.2006.04.091

[29] Alba-Loureiro, T.C., Pithon-Curi, T.C. and Curi, R. (2008) Reduced cytokine production by glycogen-elicited peritoneal cells from diabetic rats. Shock, 30, 308-310. http://dx.doi.org/10.1097/SHK.0b013e318164e834

[30] Chomczynski, P. and Sacchi, N. (1987) Single-step method of RNA isolation by acid guanidinium thiocyanatephenol-chloroform extration. Analytical Biochemistry, 162, 156-159. http://dx.doi.org/10.1016/0003-2697(87)90021-2

[31] Chomczynski, P. (1993) A reagent for the single-step simultaneous isolation of RNA, DNA and proteins from cell and tissue samples. Biotechniques, 15, 532-534.

[32] Levada-Pires, A.C., et al. (2007) Exercise training raises expression of the cytosolic components of NADPH oxi- 
dase in rat neutrophils. European Journal of Applied Physiology, 100, 153-160.

http://dx.doi.org/10.1007/s00421-007-0414-y

[33] Higuchi, M. (1992) Reduced nicotinamide adenine dinucleotide oxidase involvement in defense against oxygen toxicity of Streptococcus mutans. Oral Microbiology and Immunology, 7, 309-314. http://dx.doi.org/10.1111/j.1399-302X.1992.tb00594.x

[34] Livak, K.J. and Schmittgen, T.D. (2001) Analysis of relative gene expression data using real-time quantitative PCR and the 2(-Delta Delta C(T)) Method. Methods, 25, 402-408. http://dx.doi.org/10.1006/meth.2001.1262

[35] Pfaffl, M.W. (2001) A new mathematical model for relative quantification in real-time RT-PCR. Nucleic Acids Research, 29, e45. http://dx.doi.org/10.1093/nar/29.9.e45

[36] Zhang, X., Ding, L. and Sandford, A.J. (2005) Selection of reference genes for gene expression studies in human neutrophils by real-time PCR. BMC Molecular Biology, 6, 4. http://dx.doi.org/10.1186/1471-2199-6-4

[37] Olinescu, R., et al. (1994) Steroid hormones may modulate the chemiluminescence emission produced by polymorphonuclear leukocytes. Romanian Journal of Internal
Medicine, 32, 37-46.

[38] al-Afaleq, A.I. and Homeida, A.M. (1998) Effects of low doses of oestradiol, testosterone and dihydrotestosterone on the immune response of broiler chicks. Immunopharmacology and Immunotoxicology, 20, 315-327. http://dx.doi.org/10.3109/08923979809038547

[39] Marin, D.P., et al. (2010) Testosterone suppresses oxidative stress in human neutrophils. Cell Biochemistry and Function, 28, 394-402. http://dx.doi.org/10.1002/cbf.1669

[40] Bekesi, G., et al. (2001) Plasma concentration of myeloperoxidase enzyme in pre- and post-climacterial people: Related superoxide anion generation. Experimental Gerontology, 37, 137-148. http://dx.doi.org/10.1016/S0531-5565(01)00151-6

[41] Sumi, D., et al. (2003) 17beta-estradiol inhibits NADPH oxidase activity through the regulation of p47phox mRNA and protein expression in THP-1 cells. Biochimica et Biophysica Acta, 1640, 113-118. http://dx.doi.org/10.1016/S0167-4889(03)00026-0 